\title{
Assessment of Road-Induced Landscape Fragmentation and Implications for Landscape Planning: the case of İzmir Province
}

\author{
Yollardan Kaynaklanan Peyzaj Parçalanmasının Belirlenmesi ve Peyzaj Planlama \\ Açısından Değerlendirmeler: İzmir İli Örneği
}

\author{
Ebru ERSOY TONYALOĞLU* \\ Aydın Adnan Menderes Üniversitesi, Ziraat Fakültesi, Peyzaj Mimarlı̆̆ Bölümü, Aydın
}

• Geliş tarihi / Received: 26.03.2019 • Düzeltilerek geliş tarihi / Received in revised form: 07.04.2019 • Kabul tarihi / Accepted: 11.07 .2019

\begin{abstract}
Roads are considered as a major environmental problem and one of the main causes of biodiversity loss and landscape fragmentation. Recent evidence suggests that whilst roads generally lead to increasing landscape fragmentation; they also affect the structure and functioning of landscapes through the pollution caused by the vehicles and the acceleration of settlements around road networks. This paper explores the relationship between the presence of roads and landscape fragmentation in the central districts of Izmir province, using landscape metrics at class and landscape level. CORINE land cover (CLC2012) dataset together with Urban Atlas 2012 (UA2012) were used for the delineation of land cover map with and without roads. The analyses were performed in FRAGSTATS 4.2 and ArcGIS 10.5.1. Results illustrated an increasingly fragmented urban landscape with respect to increasing road existence. However, it is important to bear in mind the possible limitations of some landscape metrics when evaluating fragmentation caused by roads. On the other hand, the results of this study emphasise that the number of patches (NP), area-weighted mean patch area (AREA_AM), edge density (ED) and effective mesh size (MESH) seem to be much more robust landscape metric when measuring landscape fragmentation. The paper concludes with important implications and recommendations with a view to informing landscape planning practices for creating opportunities around roads and road networks to support biodiversity and enhance the lives of people. For example, as a practical manner, the creation of roadside vegetation and vegetated verges can reduce the fragmentation effect of road networks and enhance landscape connectivity rather than its fragmentation effect. The care and regular maintenance of these areas will also play an important role in improving landscape quality and promoting biodiversity.
\end{abstract}

Keywords: Fragmentation, Land cover, Landscape metrics, Roads, Spatial pattern

\section{$\ddot{\boldsymbol{O}} \boldsymbol{z}$}

Yollar, büyük bir çevre sorunu ve biyolojik çeşitlilik kaybı ile peyzaj parçalanmasının ana nedenlerinden biri olarak kabul edilmektedir. Yapılan araştırmalar, yolların genellikle artan peyzaj parçalanmasına yol açtı̆̆ını; ayrıca araçların neden olduğu kirlilik ve yol ağları etrafindaki yerleşimlerin hızla artması yoluyla peyzajların yapısı ve işleyişini de etkilediklerini ortaya koymaktadır. Bu çalışma, İmir ili merkez ilçelerinde yolların varlığı ile peyzaj parçalanması arasındaki ilişkiyi sınıf ve peyzaj düzeyinde peyzaj metriklerini kullanarak incelemektedir. Çalışmada, CORINE arazi örtüsü haritası (CLC2012) ve Urban Atlas2012 (Kent Atlası2012) (UA2012) ile birlikte kullanılarak, çalışma alanına ilişkin detayl yol verisinin içerildiği ve içerilmediği arazi örtüsü haritaları kullanılmıştır. Analizler FRAGSTATS 4.2 ve ArcGIS 10.5.1 yazılımlarında gerçekleştirilmiştir. Sonuçlar artan yol varlığının kent peyzajında artan parçalanmaya sebep olduğunu göstermektedir. Ancak, yolların neden olduğu parçalanmanın dĕgerlendirilmesinde bazı peyzaj metriklerinin etkinliklerinin olası kısıtlılıklarını göz önünde bulundurmak gerekmektedir. Diğer yandan, bu çalışmanın sonuçları, peyzaj parçalanmasını değerlendirirken yama sayısı (NP), alan ağırlıklı ortalama yama alanı (AREA_AM), kenar yoğunluğu (ED) ve etkin ăg boyutunun (MESH) peyzaj parçalanmasına ilişkin daha sağlıklı değerler sunduğunu vurgulamaktadır. Çalışma, biyolojik çeşitliliğin desteklenmesi ve insanların yaşam kalitesinin iyileştirilmesi bakımından yollar ve yol ağları çevresinde firsatlar yaratmak için peyzaj planlama uygulamalarına ışı tutabilecek bazı önemli önerilerle sonlandırılmıştır. Örneğin, pratik anlamda, yol ağlart çevresinde yol kenarı bitki örtüsü ve bitkilendirilmiş banketler, yol ağlarının parçalanma etkisini azaltabilir ve peyzaj bă̆lantılılığını arttırılabilir. Ayrıca, bu alanların korunması ve düzenli bakımı peyzaj kalitesinin arttırılmasında ve biyolojik çeşitliliğin desteklenmesinde de önemli rol oynayacaktır.

Anahtar kelimeler: Parçalanma, Arazi örtüsü, Peyzaj metrikleri, Yollar, Mekansal yapı 


\section{Introduction}

Most of the significant threats to biological diversity and natural landscapes, such as habitat conversion, reduction in habitat size or the loss of habitats are generally linked to over consumption of natural resources and the transformation of many parts of natural ecosystems into urban areas (Sweeney et al., 2007; Hanski, 2011; Yang et al., 2017). In and around the human modified landscapes, roads are generally considered to be one of the most important causes of landscape fragmentation. However, it should not be forgotten that roads are important components of urban environments since they play a key role in social and economic development, such as supporting retail and tourism, increasing the accessibility of remote areas (Riitters et al., 2004; Zhang et al., 2015). In this sense, the development of roads may cause both positive and negative effects on people and nature (Yang et al., 2017). Whilst roads generally lead to landscape fragmentation, they also affect the structure and functioning of landscapes through the pollution caused by the vehicles and the acceleration of recreation and settlement activities (Frair et al., 2008). Zhang et al. (2015) argue that roads have various potential direct and indirect impacts on nature and wildlife. Thereupon, we can claim that if the development of road networks is not controlled, and excess the capacity of environmental objectives and the nature, then this would result in increased landscape fragmentation, the loss, degradation and destruction of habitats (Forman et al., 2003; Grilo et al., 2009; Jackson and Fahrig, 2011) as well as increased the risk of species extinction (With, 2002). In addition to that some of the most obvious adverse effects, noise, air and water pollution caused by the vehicles pose an important threat on the physical and mental health, and the well-being of people (Banister, 2000; Plaut and Shmueli, 2000; Laurance et al., 2009; Bennett, 2017).

On the other hand, even though roads and road networks have widespread adverse effects on nature, habitats and people, the recent evidence shows that roads also form an extensive linear network in urban environments. In this context, Yang et al. (2017) states that, if sufficiently vegetated, roadside vegetation alongside pavements and roads can play a crucial role in mitigate the adverse effects of road networks, e.g. reducing noise, air and water pollution and serving as green corridors in urban environments. Through the development of an extensive green corridor alongside roads, roadside vegetation can provide a sheltered, comfortable and healthy walking experience in urban environments (Fukahori and Kubota, 2003; Giles-Corti et al., 2005). Moreover, if the present roadside vegetation is enriched by the components of natural vegetation cover, then they can form the backbone of a wider network for both wildlife and people.

Because of the dependency of people on transportation for various reasons some of which were mentioned earlier, it seems that the development and expansion of roads in and around urban environments will continue in the near future (Coyner, 2008). Therefore, assessing the potential effects of the fragmentation of roads on landscapes and proposing guidelines for conservation selection and planning strategies is crucial for a rapid assessment of landscape status in both the ecological and social sense (Zhang et al., 2015). These can be achieved by the identification and assessment of landscape fragmentation. Broadly speaking, landscape fragmentation or habitat connectivity can generally be measured and evaluated both structurally and functionally. Whilst the term functional connectivity refers to the behaviour and responses of dispersing organisms to the landscape structure and requires empirical data on species; structural connectivity relies to the spatial relationships of land cover / habitat patches based on land use / land cover data. In terms of functional connectivity measurements, the empirical data is generally unavailable / insufficient at larger scales. In addition to that, the requirement for behavioural data and the labourintensive nature of functional connectivity measurements make them applicable to only a small region. On the other hand, structural connectivity measurements generally focus on the actual physical connections between land cover / habitat patches and are usually derived from physical characteristics of the landscape (Watts et al., 2008).

There are a wide range of methods and tools that have been developed to quantify structural connectivity. One of the most common structural connectivity measures is landscape metrics. Even though landscape metrics have been criticised by researchers (Goodwin, 2003; Li and Wu, 2004), they appear to have potential for understanding the main characteristics of landscape connectivity. They are also relatively easier to be measured and can be applied to extensive areas compared to functional connectivity measures (Uuemaa et al., 
2009; Zhang et al., 2015). Recently, a variety of simple and easily applicable software have been developed to calculate landscape metrics and FRAGSTATS is one of the most common ones. In this study, FRAGSTATS 4.2 was used to measure landscape fragmentation since it includes a variety of landscape metrics at different hierarchical levels and freely available on the web with its user guide. Broadly speaking, landscape fragmentation / connectivity assessments are based on coarse resolution land cover maps alone and did not incorporate detailed road maps into the analyses. In this sense, this study aims to analyse the relationship between road density and landscape fragmentation in the central districts of Izmir province by addressing the following objectives (1) to measure the fragmentation caused by roads for different land cover types in the densely populated districts of Izmir province, and (2) to compare and contrast the current fragmentation levels of the landscape and different land cover types with roads and without roads.

\section{Materials and Methods}

\subsection{Study Area and Datasets}

Izmir province is located on the western Anatolia region, at the coast of the Aegean Sea $\left(38.4237^{\circ} \mathrm{N}, 27.1428^{\circ} \mathrm{E}\right)$. It has an area of $12,015 \mathrm{~km} 2$ with a population of $4,320,519$ in 2018 (TUIK, 2018). In 2018, the population growth rate was $0.95 \%$ with the population density of 360person / km2. Situated in the Mediterranean climate zone, Izmir has hot and dry summers and warm and rainy winters. Whilst the hottest months in Izmir are July and August, the coldest months are January and February (Izmir MGM, 2019). In the province of Izmir, agricultural lands occupy a large portion of the whole city, and the dominant natural vegetation is composed of Mediterranean coniferous forests and shrub vegetation (Atalay, 1994). Even though the Izmir province includes 30 districts, the case study area was selected from the densely populated urbanised districts of Izmir province including Balçova, Bayraklı, Bornova, Buca, Çiğli, Gaziemir, Karabağlar, Karşıyaka, Konak and Narlidere (Figure 1). Izmir is the third most populous city in Turkey with a dynamic economic and social environment. So, the most significant changes in the landscape is shaped by the increase in population together with development of new economic sectors which resulted in increasing housing requirement and accordingly the acceleration of new settlements and road networks. In general, settlements have been sprawled along the road networks.

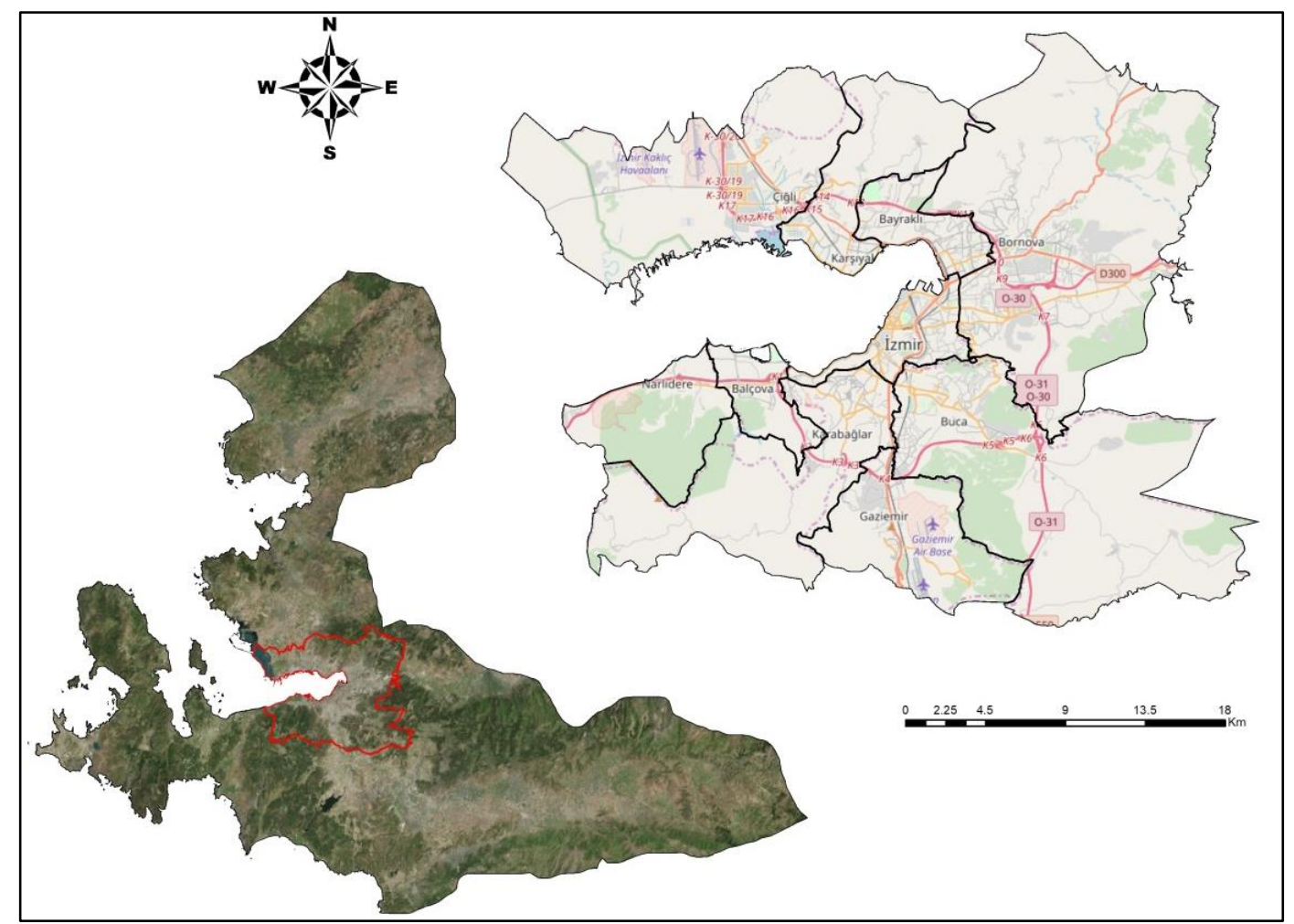

Figure 1. Study Area 
In this study, I used data sources which are easy to access and freely available from Copernicus Land Monitoring Service for the year of 2012: vector based CORINE Land Cover map-CLC2012 and Urban Atlas map-UA2012 (Copernicus Land Monitoring Services, 2018a and b). The CLC map is a result of an inventory for Europe which was initiated in 1985 by the European Union. Originally, the CLC map of land cover in 44 classes with a minimum mapping area of $25 \mathrm{ha}$ and a minimum width of $100 \mathrm{~m}$ for linear land covers (Copernicus Land Monitoring Services, 2018a). CLC2012 of the study area was composed of 28 land cover classes. In order to simplify the land cover data for analysis, these land cover classes were aggregated into 12 broad land cover types: Agricultural land; Beaches, dunes, sands; Broadleaved forests; Coniferous forests; Industrial, commercial and transport units; Mine, dump and construction sites; Mixed forests; Scrub and / or herbaceous vegetation associations; Sparsely vegetated areas; Urban fabric; Urban open and green spaces; and Water and wetlands. On the other hand, the creation of Urban Atlas data is coordinated by the European Environment Agency. The Urban Atlas map provides a comparable LULC data for the Europe with a minimum mapping area of 0.25 ha (Copernicus Land Monitoring Services, 2018b). The roads and road network was extracted from UA2012.

\subsection{Landscape Metrics and the Relationship between Roads and Landscape Fragmentation}

In an attempt to quantify the spatial relationships among landscape pattern a variety of landscape metrics have been developed. Landscape metrics generally focus on the characterisation of the geometric and spatial properties of landscape patterns and they can be computed in three levels, namely patch, class and landscape. Patch level metrics generally serve as the basis for the calculation of class and landscape level metrics. Whilst class level metrics are integrated over all the patches of a given type and quantify the amount and spatial configuration of each patch type, landscape level metrics are integrated over all patches / classes in the full extent of the landscape. Class level metrics provide a means to quantify the extent and fragmentation of each patch type in the landscape, whereas the primary interest of landscape level metrics is in the pattern of the entire landscape mosaic (McGarigal et al., 2002; Leitão et al., 2012). As the basic landscape pattern components, composition and configuration have different types of metrics and they measure different characteristics of landscapes (McGarigal et al., 2002; McGarigal, 2014; Zhang et al., 2015). Composition metrics describe the variety and abundance of the all patch types without reference to their spatial character in the landscape. On the other hand, configuration metrics require spatial information for their calculation and they refer to the spatial character, arrangement, and position of patches.

Totally 12 landscape metrics were calculated in FRAGSTSTS 4.2 including; 9 class level and 4 landscape level metrics (Table 1).

Table 1. Selected landscape metrics (Leitão et al., 2012; McGarigal, 2014)

\begin{tabular}{|c|c|c|c|}
\hline Metric & Acronym and Range & Metric Description & Reason for Selection \\
\hline Number of Patches & $\mathrm{NP} \geq 1$, without limit & $\begin{array}{l}\text { The number of patches of the given land } \\
\text { cover type (class and landscape level) }\end{array}$ & \\
\hline Patch Density & $\mathrm{PD}>0$ & $\begin{array}{l}\text { Number of patches per } 100 \text { hectares } \\
\text { (class and landscape level) }\end{array}$ & $\begin{array}{l}\text { The subdivision of } \\
\text { landscape as a simple } \\
\text { measure of } \\
\text { fragmentation }\end{array}$ \\
\hline Edge Density (m/ha) & $\mathrm{ED} \geq 0$, without limit & $\begin{array}{l}\text { The sum of the lengths of all edge } \\
\text { segments of the given land cover type, } \\
\text { divided by the total landscape area } \\
\text { (class and landscape level) }\end{array}$ & \\
\hline $\begin{array}{l}\text { Area Weighted Mean } \\
\text { Patch Area (ha) }\end{array}$ & $\begin{array}{l}\text { AREA_AM > } 0 \text {, without } \\
\text { limit }\end{array}$ & $\begin{array}{l}\text { The area weighted mean size of the } \\
\text { given land cover type (class and } \\
\text { landscape level) }\end{array}$ & $\begin{array}{l}\text { AREA is a } \\
\text { fundamental } \\
\text { characteristic of } \\
\text { landscape structure }\end{array}$ \\
\hline Total Class Area (ha) & $\mathrm{CA}>0$, without limit & $\begin{array}{l}\text { The sum of the areas of } \\
\text { all patches for the given } \\
\text { land cover type (class level) }\end{array}$ & $\begin{array}{l}\text { PLAND and CA } \\
\text { represent the } \\
\text { proportional } \\
\text { abundance of each } \\
\text { land cover type as an } \\
\text { indication of } \\
\text { dominance in the } \\
\text { landscape }\end{array}$ \\
\hline
\end{tabular}


Table 1. continued

\begin{tabular}{|c|c|c|c|}
\hline Metric & Acronym and Range & Metric Description & Reason for Selection \\
\hline $\begin{array}{l}\text { Percentage of } \\
\text { Landscape }(\%)\end{array}$ & $0<$ PLAND $\leq 100$ & $\begin{array}{l}\text { The proportion of landscape occupied by } \\
\text { a particular land cover type (class level) }\end{array}$ & \\
\hline $\begin{array}{l}\text { Area Weighted } \\
\text { Proximity Index }\end{array}$ & $\begin{array}{l}\text { PROX_AM } \geq 0 \text {, without } \\
\text { limit }\end{array}$ & $\begin{array}{l}\text { The degree of isolation and } \\
\text { fragmentation within a specified search } \\
\text { radius for the given land cover type } \\
\text { (class level) }\end{array}$ & \\
\hline $\begin{array}{l}\text { Area Weighted } \\
\text { Euclidean Nearest } \\
\text { Neighbour Distance } \\
\text { (m) }\end{array}$ & ENN_AM > 0, without limit & $\begin{array}{l}\text { The shortest edge to edge distance } \\
\text { between the adjacent patches of the } \\
\text { same land cover type (class level) }\end{array}$ & $\begin{array}{l}\text { Basic measures of } \\
\text { patch fragmentation } \\
\text { and isolation; in turn } \\
\text { spatial connectivity. }\end{array}$ \\
\hline Effective Mesh Size & $\begin{array}{l}\text { cell size } \leq \text { MESH } \leq \text { total } \\
\text { landscape area }\end{array}$ & $\begin{array}{l}\text { Gives the probability of two points } \\
\text { chosen randomly in a region will be } \\
\text { connected (class level) }\end{array}$ & \\
\hline
\end{tabular}

Selected landscape metrics include both the composition and configuration metrics. These landscape metrics were chosen because of their ability to characterise the fragmentation / isolation of a particular land cover type in the landscape and they can provide a more in-depth analysis of landscape pattern. Whilst the land cover map was used as a proxy of the non-fragmented landscape condition, landscape fragmentation caused by roads was measured after superimposing the roads on the land cover map (Figure 2).

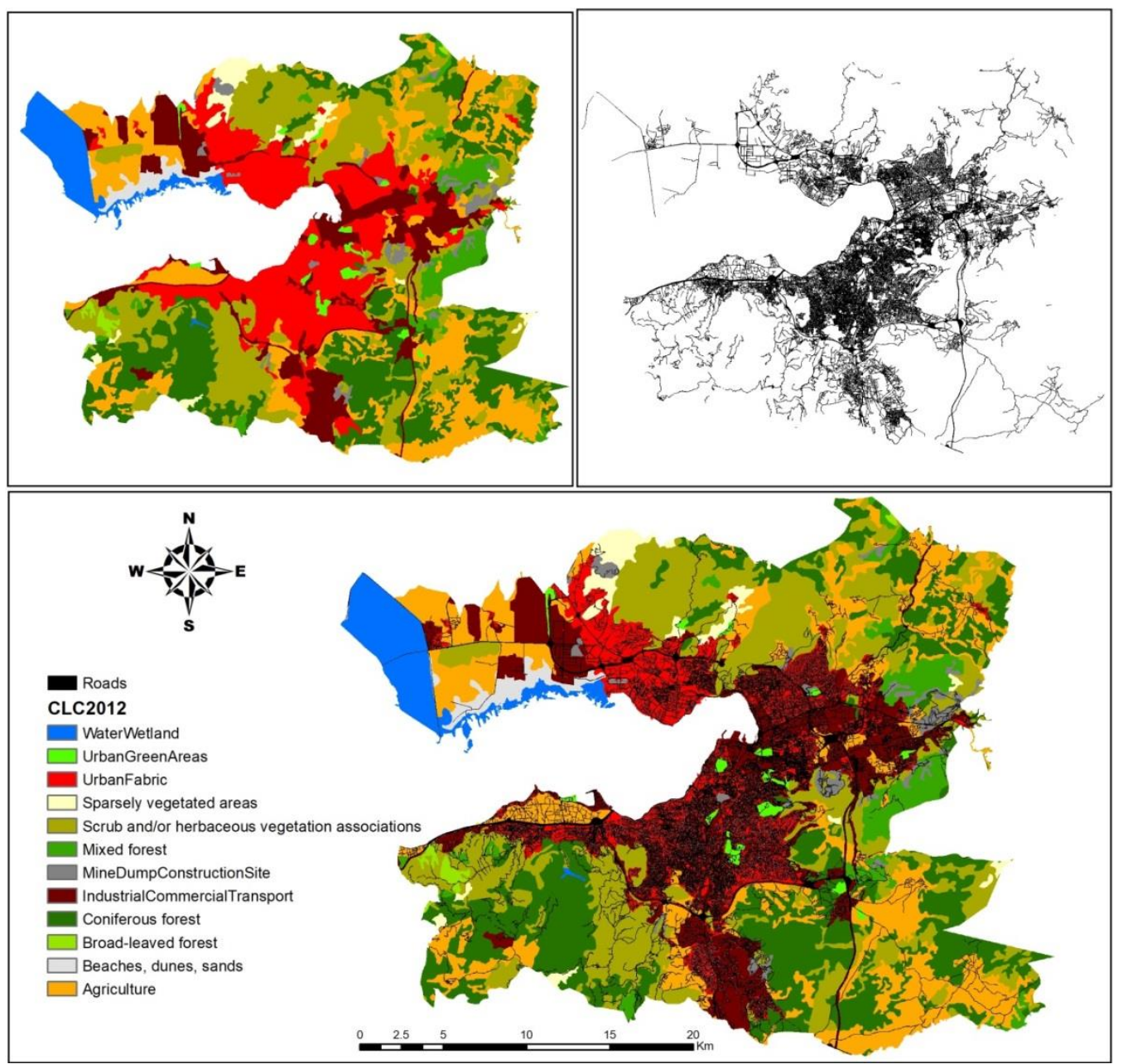

Figure 2. Land cover map, road network map and land cover after superimposing the roads 


\section{Research Findings and Discussion}

\subsection{Spatial Pattern of the Landscape}

According to the results of FRAGSTATS analysis at the landscape level for the land cover without roads, the study area is composed of 427 patches (AREA_AM=1973.95ha) with low PD (0.5) but high ED (23.12). The pattern of each land cover type was assessed on the basis of information obtained from landscape metrics through a joint interpretation of area-edge, contagion/interspersion and aggregation metrics at the class level (McGarigal et al., 2002). As the dominant land cover types, Scrub and/or herbaceous vegetation associations, Coniferous forests and Agricultural lands cover 21.91\%, $18.89 \%$ and $18.21 \%$ of the whole study area, respectively. Among these three land cover types, Scrub and/or herbaceous vegetation associations has the highest NP (98). Whilst these three land cover types reported very similar figures for PD and ED, we can safely claim that Coniferous forests represent the strongest structural connectivity in the whole landscape based on their AREA_AM, PROX_AM, ENN_AM and MESH values. The common structural properties of Mixed forests and Water and wetlands is having similar spatial extent $(3.52 \%$ and $3.90 \%$, respectively). However, whilst Water and wetlands represent stronger structural connectivity with smaller PD, ED, NP and larger AREA_AM, PROX_AM, ENN_AM and MESH values, Mixed forests represent a more scattered and isolated pattern. Covering only $6.82 \%$ of the whole study area with a small number of patches, Mixed forests (3.52\%), Sparsely vegetated areas (1.84\%), Beaches, dunes, sands $(1.11 \%)$ and Broad-leaved forests $(0.35 \%)$ reported more isolated and fragmented spatial pattern compared to the other natural and semi-natural land cover types. Occupying only $0.81 \%$ of the total study area, urban open and green spaces have the second lowest PROX_AM and MESH values. Together with its small sized patches and relatively high $\mathrm{ED}$, these figures can be evaluated as an indication of the high fragmentation and isolation. Another important finding of the landscape pattern analysis is that Urban fabric, Industrial, commercial and transport units, and Mine, dump and construction sites occupy almost one third of the whole landscape in the study area (29.47\%). Among these there land cover types, Urban fabric occupies $17.04 \%$ of the whole study area with the largest AREA_AM (3698.50ha) and relatively small NP (31). With a very similar NP, PD and ED values Industrial, commercial and transport units reported higher MESH value compared to the patches of Urban fabric land cover type. Taking into account these results together with PROX_AM and ENN_AM for Urban fabric and Industrial, commercial and transport units, it seems that Urban fabric has relatively stronger structural connectivity. Finally, in comparison with the other artificial land cover types, Mine, dump and construction sites occupy the smallest land $(1.71 \%)$ with a small number of scattered and isolated patches in the whole study area.

\subsection{Landscape Fragmentation Caused by Roads}

As seen in Figure 2, roads are generally centred on urban fabric of Bayrakl1, Bornova, Buca, Karabağlar, Karşıyaka, Konak districts along the coastal area and spread into the natural and seminatural land cover types which are sparsely populated. Whilst the land cover map without roads was used as a proxy of the non-fragmented landscape condition, landscape fragmentation caused by roads was measured after superimposing the roads on the land cover map and by calculating and comparing the results of the same class and landscape level metrics on this map. The overall results of the spatial analysis at class and landscape levels for the land cover without roads and after superimposing roads are given in Table 2 and 3. As expected superimposing the road map on the land cover map eliminated the total area of all land cover types in the study area. The total landscape area is decreased from 84856.67ha to 79710.23ha indicating that roads cover $6.06 \%$ (5146.44ha) of the whole study area. Here, it is important to note that even though roads form a large part of artificial surfaces in urban environments, because they are extracted from other artificial land cover types, the total area of those decreased, too. However, since the scope of this paper is to evaluate the landscape fragmentation of natural and semi-natural land cover types which is thought to be caused by roads, artificial surfaces are excluded from the evaluations.

At the landscape level, the number of patches reported a large increase (from 427 to 22801) with a decrease in AREA_AM of almost two third. These substantial changes in the total number and area of patches also imply the large extent of road network distribution in the study area. In addition to this, considering the larger values for PD and ED, we can safely claim that the whole landscape became much patchier and fragmented compared to the previous landscape condition. 


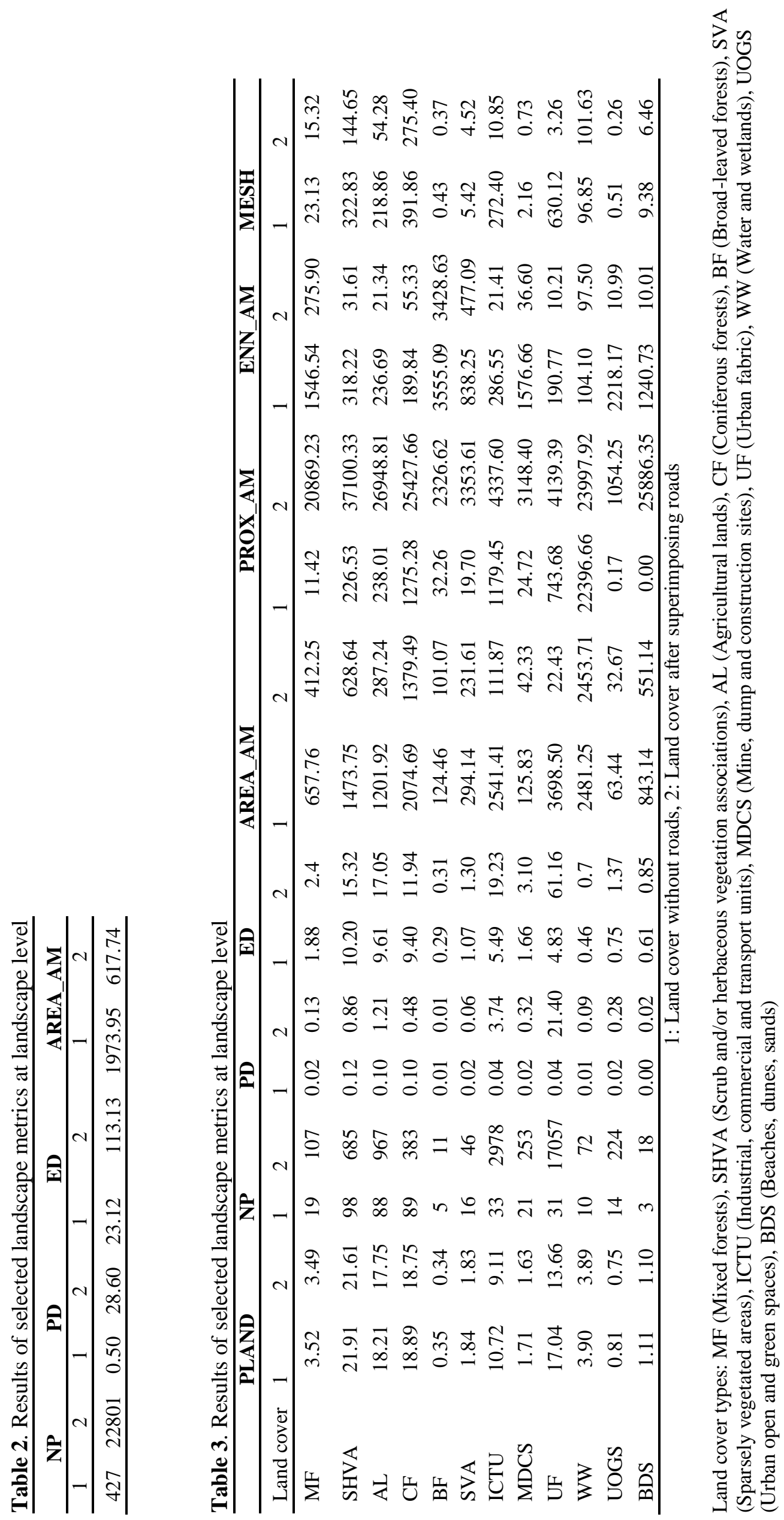


Contrary to expectations, superimposing roads over the land cover types in the study area eliminated only $1.42 \%$ of the natural and seminatural land cover types (848.76ha). This might be attributed to the fact that the amount of tracks (which are not included in road network) is much more than the sealed roads where there are large patches of forests and other natural and seminatural land cover types present. But yet, for all the natural and semi-natural land cover types, the change in AREA_AM and MESH values generally indicate that the incorporation of roads into landscape has much more adverse effects on landscape fragmentation.

Amongst all the natural and semi-natural land cover types, the largest decrease is seen in the area of Scrub and/or herbaceous vegetation associations (246.62ha). Also, superimposing roads into the land cover map caused Scrub and/or herbaceous vegetation associations to become structurally more fragmented with a higher number of small sized patches (NP from 98 to 685, AREA_AM from 1473.75 ha to 628.64ha). Coniferous forests have also experienced a substantial increase in its NP (around 4.5 times) with increasing $\mathrm{PD}$ and $\mathrm{ED}$, and decreasing AREA_AM and MESH values. A similar change is observed in the spatial pattern of Mixed forests, Sparsely vegetated areas, Broad-leaved forests, Water and wetlands and Beaches, dunes, sands. Finally, the comparison of the results of landscape metrics for Urban open and green spaces imply an increased fragmentation in its pattern. However, these areas are mainly centred on the built-up areas in urban fabric and surrounded by roads to provide accessibility for the public. These figures may not accurately describe road caused fragmentation in the landscape for Urban open and green spaces. For each land cover type, both ENN_AM and PROX_AM indicated that adding much more road into the landscape would actually reduce landscape fragmentation. So, it was concluded that the behaviour of these metrics was inconsistent as an indication of fragmentation in the study area.

These findings broadly support the work of other studies in this area linking the presence of roads with landscape fragmentation. Roads are continuous and linear features which are connected to each other in the form of networks and spread over other land cover types in urban environments (Riitters et al., 2004). In additon to its direct influences, the presence of roads might have a variety of indirect impacts on nature, such as decreasing habitat quality (Riitters et al., 2004;
Bennett, 2017). Also, generally spoken these effects seem to become greater because of the fact that roads encourage the development of new houses and facilities around roads and vice versa (Hawbaker et al., 2006; Ribeiro et al., 2016). As expected, the hot spots of roads are mainly concentrated around built-up areas, since these areas have a long history in land use, urban and transportation development and accordingly they constitute the backbone of accessibility routes for a variety of activity in urban environments, such as supporting retail and tourism (Cai et al., 2013; Riitters et al., 2004). Superimposing the road maps on the land cover map resulted in an increase in fragmentation on the whole landscape and also on individual land cover types. Moreover, this process reduced the total amount of natural and semi-natural land cover types and to some extent, and resulted in the dissection of the natural and semi-natural land-cover types. However, the substantial change found in the results could also be a result of overlaying maps with different resolutions (Riitters et al., 2004), and so these results therefore need to be interpreted with caution.

Methodologically, as with Riitters et al. (2004) claimed, we can say that some landscape metrics do not work very well to explain the level of fragmentation caused by roads. For example, according to decreasing ENN_AM and increasing PROX_AM values after superimposing the road maps on the land cover map, we can suggest that the adding much more road into the landscape would actually reduce landscape fragmentation in the study area. This inconsistency may be due to the creation of small patches when overlaying maps with different resolutions. As argued by Riitters et al. (2004), an acceptable landscape metric as a measure of fragmentation should behave in a logical direction and the changes in its values should be consistent for different land cover types at different locations. On the other hand, number of patches (NP), area-weighted mean patch area (AREA_AM), edge density (ED) and effective mesh size (MESH) seem to be much more robust landscape metric when measuring landscape fragmentation.

Finally, even though roads and road networks have detrimental effects on landscapes, nature, biodiversity and people, there are ways of using the roads and road networks as the backbone of an extensive ecological corridor, to reverse its adverse effects and maximise its potential for biodiversity and people. It is important to note that there are evidences that show roadside 
vegetation and vegetated verges have potential to support a variety of species when sufficiently vegetated and managed (Auestad et al., 2011; O'Sullivan et al., 2017; Jakobsson et al., 2018). Accordingly, by constituting an extensive linear network of vegetated areas, roads and road networks can support landscape connectivity rather than its fragmentation effect. Finally, as suggested by O'Sullivan et al. (2017), the management of roadside vegetation alongside road networks is crucial in providing connected and functioning ecosystems in urban landscapes, particularly where we lost existing green spaces and have expanding road networks.

\section{Conclusions}

In this paper, the aim was to explore the relationship between the presence of roads and landscape fragmentation in the central districts of Izmir province, using landscape metrics at class and landscape level. the development and presence of roads in urban environments is an inevitable result of urban development, and for sure the development and expansion of road networks in and around urban environments will continue in the near future (Coyner, 2008). Therefore, from a planning point of view it is important to find ways of how we can mitigate the adverse effects of roads. As mentioned earlier, one of the ways of doing this can be the use and management of roadside vegetation and sufficiently vegetated verges to enhance the landscape and support biodiversity (Hambrey Consulting, 2013; O'Sullivan et al., 2017). For example, Lawton et al. (2010) suggest that habitat creation can allow a more gradual transition between the boundaries of existing habitats and other land uses. In this case, $6.06 \%$ (5146.44ha) of the study area is composed of road networks. This means that if we create roadside vegetation and sufficiently vegetated verges along road networks, we can mitigate its adverse effects on nature and biodiversity and enhance its potential for biodiversity. In addition, roadside vegetation together with paths and pavements can constitute the backbone of functional accessibility routes for people since they are generally accessible to the public and provide linear connections in between urban green and open spaces (Moseley et al., 2013). Hence, we can safely claim that roads and road networks can be used as a crucial component in the landscape to create much more liveable landscapes for wildlife and people. Finally, the care and regular maintenance of these areas will also play an important role in improving landscape quality and promoting biodiversity (Kettunen et al., 2007).

It is a well-known fact that the expanding road networks are a major contribution to the fragmentation of landscapes. It is important to measure the degree of fragmentation caused by roads and road networks. The results of this study are in agreement with the previous research which suggests that roads lead increasing fragmentation in the landscape (e.g. Riitters et al., 2004; Zhang et al., 2015). When the roads are superimposed on the land cover map, both the whole landscape and different land cover types are dissected and become more fragmented. This study has also shown the importance of specific landscape metrics in fragmentation analysis since the behaviour of some landscape metrics gave inconsistent interpretations in terms of the aim of this study. For example, whilst NP, AREA_AM, ED and MESH seem to be much more robust landscape metrics to explain the level of fragmentation caused by roads, ENN_AM and PROX_AM do not work very well (Riitters et al., 2004). Therefore, we should use and test a variety of landscape metrics which are all known to be highly suitable as indicators for monitoring fragmentation and select the results of which can provide a comprehensive description of fragmentation in our case study area.

\section{References}

Atalay, I. 1994. Vegetation geography of Turkey. Ege University Press, Izmir, Turkey.

Auestad, I., Rydgren, K. and Austad, I., 2011, August. Road verges: potential refuges for declining grassland species despite remnant vegetation dynamics. In Annales botanici fennici (Vol. 48, No. 4, pp. 289-304). Finnish Zoological and Botanical Publishing Board.

Banister, D., 2000. Sustainable urban development and transport-a Eurovision for 2020. Transport Reviews, 20(1), pp.113-130.

Bennett, V.J., 2017. Effects of road density and pattern on the conservation of species and biodiversity. Current Landscape Ecology Reports, 2(1), pp.111.

Cai, X., Wu, Z. and Cheng, J., 2013. Using kernel density estimation to assess the spatial pattern of road density and its impact on landscape fragmentation. International Journal of Geographical Information Science, 27(2), pp.222-230. 
Copernicus Land Monitoring Services, 2018a. CORINE Land Cover 2012. Retrieved January 10, 2018, from https://land.copernicus.eu/paneuropean/corine-land-cover/clc-2012

Copernicus Land Monitoring Services, 2018b. Urban Atlas 2012. Retrieved January 10, 2018, from https://land.copernicus.eu/local/urbanatlas/urban-atlas-2012

Coyner, B.S., 2015, February. An Assessment of Habitat Fragmentation by Roads in Cimarron County, Oklahoma. In Proceedings of the Oklahoma Academy of Science (Vol. 88, pp. 2126).

Forman, R.T., Sperling, D., Bissonette, J.A., Clevenger, A.P., Cutshall, C.D., Dale, V.H., Fahrig, L., France, R.L., Heanue, K., Goldman, C.R. and Jones, J., 2003. Road ecology: science and solutions. Island press.

Frair, J.L., Merrill, E.H., Beyer, H.L. and Morales, J.M., 2008. Thresholds in landscape connectivity and mortality risks in response to growing road networks. Journal of applied ecology, 45(5), pp.1504-1513.

Fukahori, K. and Kubota, Y., 2003. The role of design elements on the cost-effectiveness of streetscape improvement. Landscape and Urban Planning, 63(2), pp.75-91.

Giles-Corti, B., Broomhall, M.H., Knuiman, M., Collins, C., Douglas, K., Ng, K., Lange, A. and Donovan, R.J., 2005. Increasing walking: how important is distance to, attractiveness, and size of public open space?. American journal of preventive medicine, 28(2), pp.169-176.

Goodwin, B.J., 2003. Is landscape connectivity a dependent or independent variable?. Landscape ecology, 18(7), pp.687-699.

Grilo, C., Sousa, J., Ascensão, F., Matos, H., Leitão, I., Pinheiro, P., Costa, M., Bernardo, J., Reto, D., Lourenço, R. and Santos-Reis, M., 2012. Individual spatial responses towards roads: implications for mortality risk. PLoS One, 7(9), p.e43811.

Hambrey Consulting. (2013) The management of roadside verges for biodiversity. Scottish Natural Heritage Commissioned Report No. 551. Retrieved June 15, 2019, from: http://www.snh.org.uk/pdfs/publications/commi ssioned_reports/551.pdf

Hanski, I., 2011. Habitat loss, the dynamics of biodiversity, and a perspective on conservation. Ambio, 40(3), pp.248-255.

Hawbaker, T.J., Radeloff, V.C., Clayton, M.K., Hammer, R.B. and Gonzalez-Abraham, C.E.,
2006. Road development, housing growth, and landscape fragmentation in northern Wisconsin: 1937-1999. Ecological Applications, 16(3), pp.1222-1237.

Izmir MGM, 2019. Meteoroloji 2. Bölge Müdürlüğü İzmir, Bölgemize Bağlı İllerin İklimi Durumu. Retrieved January 25, 2018, from http://izmir.mgm.gov.tr/FILES/iklim/izmir_ikli m.pdf

Jackson, N.D. and Fahrig, L., 2011. Relative effects of road mortality and decreased connectivity on population genetic diversity. Biological Conservation, 144(12), pp.3143-3148.

Jakobsson, S., Bernes, C., Bullock, J.M., Verheyen, K. and Lindborg, R., 2018. How does roadside vegetation management affect the diversity of vascular plants and invertebrates? A systematic review. Environmental Evidence, 7(1), p.17.

Kettunen, M., Terry, A., Tucker, G. and Jones, A., 2007. Guidance on the maintenance of landscape connectivity features of major importance for wild flora and fauna. Guidance on the implementation of Article, 3.

Laurance, W.F., Goosem, M. and Laurance, S.G., 2009. Impacts of roads and linear clearings on tropical forests. Trends in ecology \& evolution, 24(12), pp.659-669.

Lawton, J.H., Brotherton, P.N.M., Brown, V.K., Elphick, C., Fitter, A.H.,Forshaw, J., Haddow, R.W., Hilborne, S., Leafe, R.N., Mace, G. M., Southgate, M.P., Sutherland, W.J., Tew, T.E., Varley, J. \& Wynne, G.R., 2010. Making Space for Nature: a review of England"s wildlife sites and ecological network. Report to Defra.

Leitão, A.B., Miller, J., Ahern, J. and McGarigal, K., 2012. Measuring landscapes: A planner's handbook. Island press.

Li, H. and Wu, J., 2004. Use and misuse of landscape indices. Landscape ecology, 19(4), pp.389-399.

McGarigal, K., Cushman, S.A. and Ene, E., 2002. FRAGSTATS v4: Spatial pattern analysis program for categorical and continuous maps. University of Massachusetts, Amherst, MA, USA. goo. gl/aAEbMk.

McGarigal, K., 2014. FRAGSTATS help. Documentation for FRAGSTATS, 4.

Moseley, D., Marzano, M., Chetcuti, J. \& Watts, K., 2013. Green networks for people: Application of a functional approach to support the planning and management of greenspace. Landscape and Urban Planning. 116 (2013). p. 1-12. 
O'Sullivan, O.S., Holt, A.R., Warren, P.H. and Evans, K.L., 2017. Optimising UK urban road verge contributions to biodiversity and ecosystem services with cost-effective management. Journal of environmental management, 191, pp.162-171.

Plaut, P.O. and Shmueli, D.F., 2000. Sustainable Transport-A Comparative Analysis of Israel, the Netherlands and the United Kingdom Pnina O. Plaut \& Deborah F. Shmueli. Editorial board, 6(1), pp.40-58.

Ribeiro, M.C., de Lara Muylaert, R., Dodonov, P., Ciocheti, G., Magioli, M., Martello, F., Rocha, A., Borges, B.D., Carvalho, C., Kanda, C.Z. and Rodriguez-Castro, K.G., 2016. 4. Dealing with fragmentation and road effects in highly degraded and heterogeneous landscapes. In Biodiversity in Agricultural Landscapes of Southeastern Brazil (pp. 43-64). Sciendo Migration.

Riitters, K., Wickham, J. and Coulston, J., 2004. Use of road maps in national assessments of forest fragmentation in the United States. Ecology and Society, 9(2).

Sweeney, S., Engindeniz, E. and Gündüz, S., 2007. Ecological concepts necessary to the conservation of biodiversity in urban environments. A| Z ITU Journal of the Faculty of Architecture, 4(1), pp.56-72.

TUIK, 2018. Konularına Göre İstatistikler, Adrese Dayalı Nüfus Kayıt Sistemi. Retrieved January
25, 2018, from http://www.tuik.gov.tr/PreTablo.do?alt_id=1059

Uuemaa, E., Antrop, M., Roosaare, J., Marja, R. and Mander, Ü., 2009. Landscape metrics and indices: an overview of their use in landscape research. Living reviews in landscape research, 3(1), pp.1-28.

Watts, K., Handley, P., Scholefield, P. and Norton, L., 2008. Habitat Connectivity-Developing an indicator for UK and country level reporting. Phase 1 Pilot Study contract report to Defra. Forest Research \& Centre for Ecology \& Hydrology.

With, K.A., 2002. Landscape Connectivity and Metapopulation Dynamics. 08-227, In Learning landscape ecology: A practical guide to concepts and techniques. (Eds) S.E. Gergel and M.G. Turner. Springer- Verlag. New York.

Yang, X., Wang, L., Wu, T. and Qiu, Q., 2017. Ecological risk assessment based on road network development analysis of Xiamen city, China. International Journal of Sustainable Development \& World Ecology, 25(5), pp.458467.

Zhang, L., Dong, T., Xu, W. and Ouyang, Z., 2015. Assessment of habitat fragmentation caused by traffic networks and identifying key affected areas to facilitate rare wildlife conservation in China. Wildlife Research, 42(3), pp.266-279. 